\title{
Histopathological and biochemical effect of quercetin on monosodium glutamate supplementation-induced testicular toxicity
}

Manal Abdul-Hamid* ${ }^{*}$, Sanaa Rida Galaly, Rasha Rashad Ahmed and Hadeer Mohamed Hamdalla

\begin{abstract}
Background: Despite the wide usage of monosodium glutamate (MSG) as a flavor enhancer in many types of food, it has been reported as a toxic agent to humans and experimental animals. It also adversely influences male fertility. Several research studies attributed detrimental effects of MSG on reproductive organs to oxidative stress. The current study investigated the effects of MSG on testis and the potential role of quercetin in attenuating them.

Results: MSG-treated rats showed a considerable elevation in lipid peroxidation level and reduction in glutathione concentration, superoxide dismutase (SOD), and glutathione peroxidase (GPx) activities in the homogenate of testis tissues. Treatment with quercetin in combination with MSG provided significant protection. When QU was used, the toxic side effects were significantly reduced, with a considerable reduction in lipid peroxidation and an increase in SOD and GPx activities, and glutathione concentration.
\end{abstract}

Conclusions: Quercetin may be used in combination with MSG to improve the histopathological, ultrastructure, oxidative stress, and biochemical parameters of testicular toxicity induced by MSG due to its antioxidant effects.

*Correspondence: medo_bio@yahoo.com; manal.mohamed3@science.bsu.

edu.eg

Histology and Cell Biology Division, Zoology Department, Faculty

of Science, Beni-Suef University, Beni Suef 62521, Egypt 


\section{Graphical abstract:}

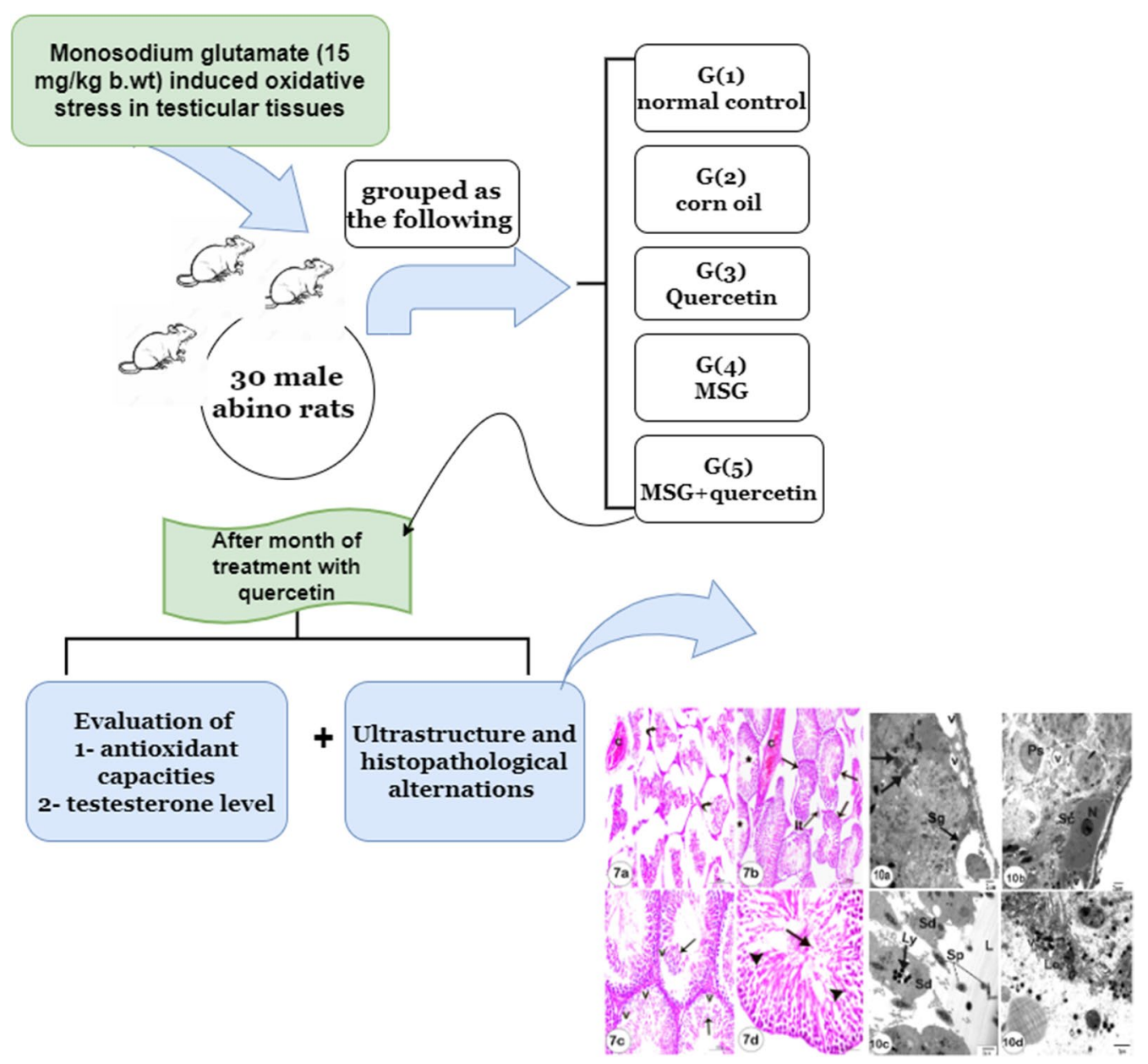

Keywords: Monosodium glutamate, Quercetin, Testis, Histopathology, Ultrastructure, Oxidative stress

\section{Background}

Monosodium glutamate (MSG) is the sodium salt of glutamic acid [1]. Glutamate is one of the most often encountered amino acids in nature. [2]. MSG produces a flavor called umami savory" [3]. Its use as a flavor in cooking has grown in popularity across the world in recent years [4]. MSG delivers umami flavor to food only when it is present in its free form, not when it is linked along with other amino acids in protein $[5,6]$. Free glutamate liberates during the fermentation of starch, sugar, beet, sugarcane or molasses, aging, ripening, and heat cooking process $[6,7]$.

MSG has been reported as toxic to humans and experimental animals [8-11]. According to previous studies, MSG has the capacity to cause a wide range of harmful adverse effects on organs, including the liver $[12,13]$ and ovary $[14,15]$. Furthermore, Pavlovic et al. [16] have indicated that administration high concentration of MSG induced oxidative stress in rat thymus, which could possibly mediate thymocyte apoptosis triggered by MSG.

Dysfunction of male reproductive is a case whereas malfunctioning of structures of the male reproductive system occurs as a result of various factors such as diet, reactive oxygen species (ROS), hormonal disorders, testicular inflammation, endocrinal disturbance, genital infection, chronic health problems, and genetic defects [11].

Monosodium glutamate has been reported to impair testicular enzyme activities, induce oligozoospermia and severe histological alternations, increases abnormal sperm morphology and infertility alternations [17-20].

Many research studies have been conducted on the utilization of natural antioxidants and dietary supplements. Phenolic chemicals, such as flavonoids, not only extend 
the shelf life of food but also function as antioxidants in a variety of biological systems [21-24]. Quercetin (QU) is a flavonoid found mostly in apples, tea, onions, almonds, cauliflower, cabbage, and a variety of other foods. It has anticarcinogenic [24, 25], anti-inflammatory [26], antiviral, and antibacterial effects [27, 28].

Quercetin has been reported to be a powerful antioxidant [25]. Its high antioxidant activity is due to the presence of aromatic hydroxyl groups in its structure [29]. There are several hypotheses to explain the antioxidant mechanisms by quercetin including oxygen radical scavenging and provides protection against lipid peroxidation [30], metal ion chelation, and modulation of cell antioxidant responses [31]. It also protects macrophages from oxidative stress by keeping glutathione in its reduced form [32].

Several studies [33, 34] have demonstrated quercetin's protective properties against different toxic agents and generated oxidative stress in several organs. A study by Farombi and Onyema [35] has indicated that QU effectively attenuated MSG-induced lipid peroxidation and modulated altered antioxidant status and antioxidant capacities in liver, kidney and brain of the rat. Furthermore, a recent study revealed that QU alleviated MSGinduced excitotoxicity of the spinal cord tissue in aged rats by suppressing the induced oxidative stress and impeding the programmed cell death via targeting p38 MAPK pathway [36]. On the other hand, although, quercetin is used as a supplementary diet for various health benefits, there are safety concerns regarding its use especially in cancer patients [37]

Thus, this study is designed to explore the protective benefits of quercetin against MSG-related testicular toxicity.

\section{Methods}

\subsection{Chemicals}

Monosodium glutamate (MSG) and quercetin (QU) were purchased from Sigma-Aldrich (Nasr City, Cairo, Egypt). The biochemical kits were purchased from Human Diagnostics Chemical Company, Germany.

\subsection{Animals}

Thirty white male albino rats (Rattus norvegicus) from VACSERA (the Egyptian Organization for Biological Vaccine Production breeding unit, Cairo, Egypt) weighting about 140-160 g. Animals were kept under observation for about 15 days before the onset of the experiment to exclude any intercurrent infections and were housed in stainless steel cages in the department of animal house and given enough food and water ad-libitum. The animals were weighed weekly during the experimental periods. At the end of experiment, the rats were sacrificed by anesthesia inhalation under light diethyl ether (5\%). This study was carried out according to the guidelines by the Animal Ethics Committee (Approval number is BSU/FS/ 2015/9).

\subsection{Experimental design}

Male albino rats were grouped as the following (six animals each):

- Group (1): Normal control group was administered distilled water.

- Group (2): received corn oil as the vehicle in a volume relevant to quercetin orally daily for 30 days.

- Group (3): were given quercetin (14 mg/kg b. wt.) dissolved in $2.5 \mathrm{~mL}$ of water daily for 30 days orally by gastric intubation [38].

- Group (4): received MSG (15 mg/kg b. wt.) dissolved in $2.5 \mathrm{~mL}$ of water daily for 30 days [39].

- Group (5): received an oral dose of MSG (15 mg/kg b. wt.) followed by quercetin $(14 \mathrm{mg} / \mathrm{kg}$ b. wt)) for 30 days.

\subsection{Blood sampling}

After coagulation at room temperature, blood samples was centrifuged at $3000 \mathrm{r}$. p. m for $15 \mathrm{~min}$, the serum samples were removed and kept at $-20{ }^{\circ} \mathrm{C}$ until for testosterone estimation.

\subsection{Tissues sampling and homogenate preparation}

Rats in each group were sacrificed under moderate anesthesia at the end of the experiment. Around $0.5 \mathrm{~g}$ of testes tissues were removed quickly, ice-cooled and homogenized in $5 \mathrm{~mL}$ of $0.9 \% \mathrm{NaCl}(1$ percent w/v) using a Teflon homogenizer (Glas-Col, Terr Haute, IN, USA). The homogenate was centrifuged at $3000 \mathrm{~g}$ for $15 \mathrm{~min}$ at $4^{\circ} \mathrm{C}$. The supernatant was collected and preserved at $-20{ }^{\circ} \mathrm{C}$ until use. Lipid peroxidation, glutathione content (GSH), glutathione peroxidase (GPx), and superoxide dismutase (SOD) activity are all measured as part of the antioxidant defence system. Furthermore, for histological investigations, portions of testes tissues were preserved in neutral buffered formalin.

\subsection{Antioxidant-capacity assay}

\subsubsection{Determination of lipid peroxidation level}

Lipid peroxidation in testes homogenate was assessed according to Pressus et al. [40]. Malondialdehyde (MDA) formed from the breakdown of polyunsaturated fatty acids serves as a convenient index for determining the extent of lipid peroxidation. Lipid peroxidation products are quantified by their reaction with thiobarbituric acid. 


\subsubsection{Determination of glutathione content}

Glutathione content (GSH) level was measured according to Beutler et al. [41]. The method based on the reduction of 5,5'dithiobis (2-nitrobenzoic acid) (DTNB) with glutathione $(\mathrm{GSH})$ to produce a yellow compound. The reduced chromogen directly proportional to GSH concentration and its absorbance can be measured at $405 \mathrm{~nm}$.

\subsubsection{Determination of glutathione peroxidase activity}

Glutathione peroxidase activity (GPx) activity was determined according to Paglia and Valentine [42]. The assay is an indirect measure of the activity of c-GPx. Oxidized glutathione (GSSG), produced upon reduction of an organic peroxide by c-GPx, is recycled to its reduced state by the enzyme glutathione reductase. The oxidation of NADPH to NADP + is accompanied by a decrease in absorbance at $340 \mathrm{~nm}$ (A340) providing a spectrophotometric means for monitoring GPx enzyme activity.

\subsubsection{Determination of superoxide dismutase activity}

Finally, according to Nishikimi et al., [43], this assay relies on the ability of the purified SOD to inhibit the initial rate of photo activated phenazine methosulphate-mediated reduction of $\mathrm{O}^{\circ}$ to $\mathrm{O} 2$ which then reduced nitroblue tetrazolium dye. $1.5 \mathrm{U} /$ assay of the purified enzyme produced $80 \%$ inhibition.

\subsection{Determination of testosterone level}

Serum testosterone was determined by ELISA, based on the principle of competitive binding, according to Huang et al. [44] Darney [45] and Sakuma et al. [46]. The testosterone (an unknown amount) presents in the sample and a defined amount of testosterone conjugated to horseradish peroxidase compete for the binding sites of testosterone antiserum coated to the wells of a microplate, incubated for one hour on a shaker and then the microplate is washed four times. After addition of the substrate solution, the concentration of testosterone is inversely proportional to the optical density measured.

\subsection{Light microscopic study}

Paraffin sections prepared according to Bancroft et al. [47]. Testicular tissue samples were fixed in $10 \%$ neutral buffered formalin ( $\mathrm{pH}$ 6.8). Then, tissue samples were dehydrated before being embedded in paraffin wax, sectioned at $4-5 \mu \mathrm{m}$, and stained with hematoxylin and eosin for histological analysis.

\subsection{Transmission electron microscope (TEM) preparation} TEM thin sections were processed as reported by Bozzola and Russell [48]. 1-3 mm segments of testis were promptly fixed in $3 \%$ glutaraldehyde (freshly prepared), washed in phosphate buffer $(\mathrm{pH} 7.4)$ and then postfixed in osmium tetroxide (1\%). Then, the samples were embedded in fresh pure resin at room temperature overnight before being transferred to capsules containing fresh resin. Semi-thin sections of testis tissues were cut and stained with toluidine blue. Ultrathin sections were prepared and stained to be examined on a TEM (model CX 100, JEOL, Japan) operated at $60 \mathrm{kV}$.

\subsection{Statistical analysis}

Data were analyzed using one way analysis of variance (PC-STAT software program) followed by least significant degree (LSD) analysis to evaluate multiple comparisons between different groups [49]. The data are presented as means \pm Standard error, and values of $P<0.01$ and $P<0.001$ are significantly different.

\section{Results}

\subsection{Antioxidant-capacity assay}

The MSG-treated group displayed a significant increase in level of MDA level in comparison to their respective control group (Fig. 1). Also, MSG administration resulted in a significant reduction in GSH content tissue along with GPx and SOD activities (Figs. 2, 3, 4) respectively. However, simultaneous administration of QU along with MSG significantly $(P<0.0001)$ mitigated the altered level of GSH, GSH-Px, and SOD activities when compared with MSG-treated group. When compared with the control and corn oil groups, rats treated with QU only depicted nearly comparable outcomes.

The observed changes in serum testosterone are shown in (Fig. 5). A significant decrease in serum testosterone level in MSG-treated rats compared to the control rats was observed. Administration of QU to MSG-treated rats revealed a significant $(P<0.0001)$ amelioration in the altered level of testosterone when compared with the MSG-treated group.

\subsection{Histopatological results}

Testes of control rats (Fig. 6a-d) and quercetin treated rats (Fig. 6e and f) showed a normal morphology for the seminiferous tubules and interstitial tissue containing Leydig cells. Each tubule possessed epithelial cells involving Sertoli cells and germ cells which showed the complete process of spermatogenesis (Fig. 1b, d, and f). Sertoli cells contain irregular nuclei, which were usually found toward the basement membrane of the seminiferous tubule. Spermatogonia were oval in shape, resting upon the basal lamina of the seminiferous tubule, above them were spherical primary spermatocytes, recognized by their copious cytoplasm and large nuclei containing coarse clumps of chromatin (Fig. 6b, d, and f). MSG-treated rats' testicular tissues 


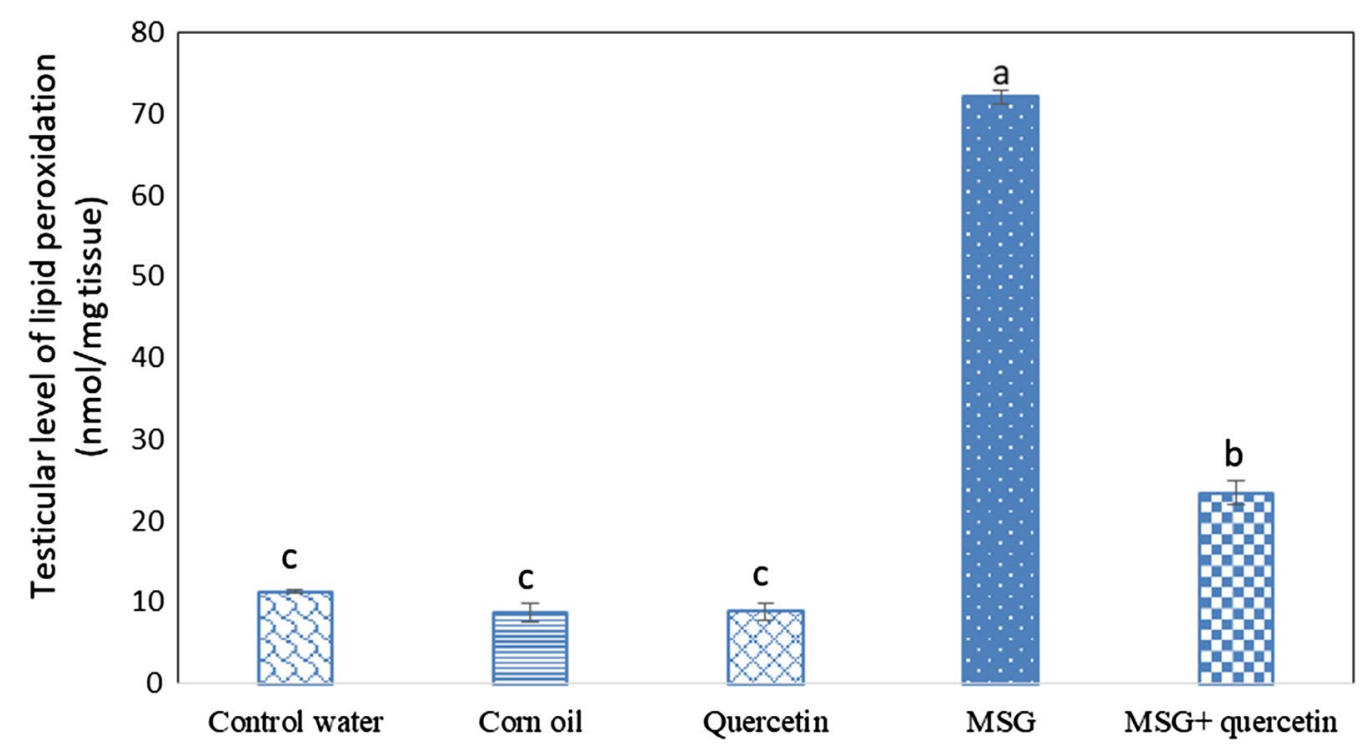

Fig. 1 Changes in the level of lipid peroxidation (nanomole per milligram tissue) in testis among all tested groups. The number of samples in each group is six. Values were expressed as mean \pm standard error. Means which share different superscript symbol(s) are significantly different at $P<0.001$

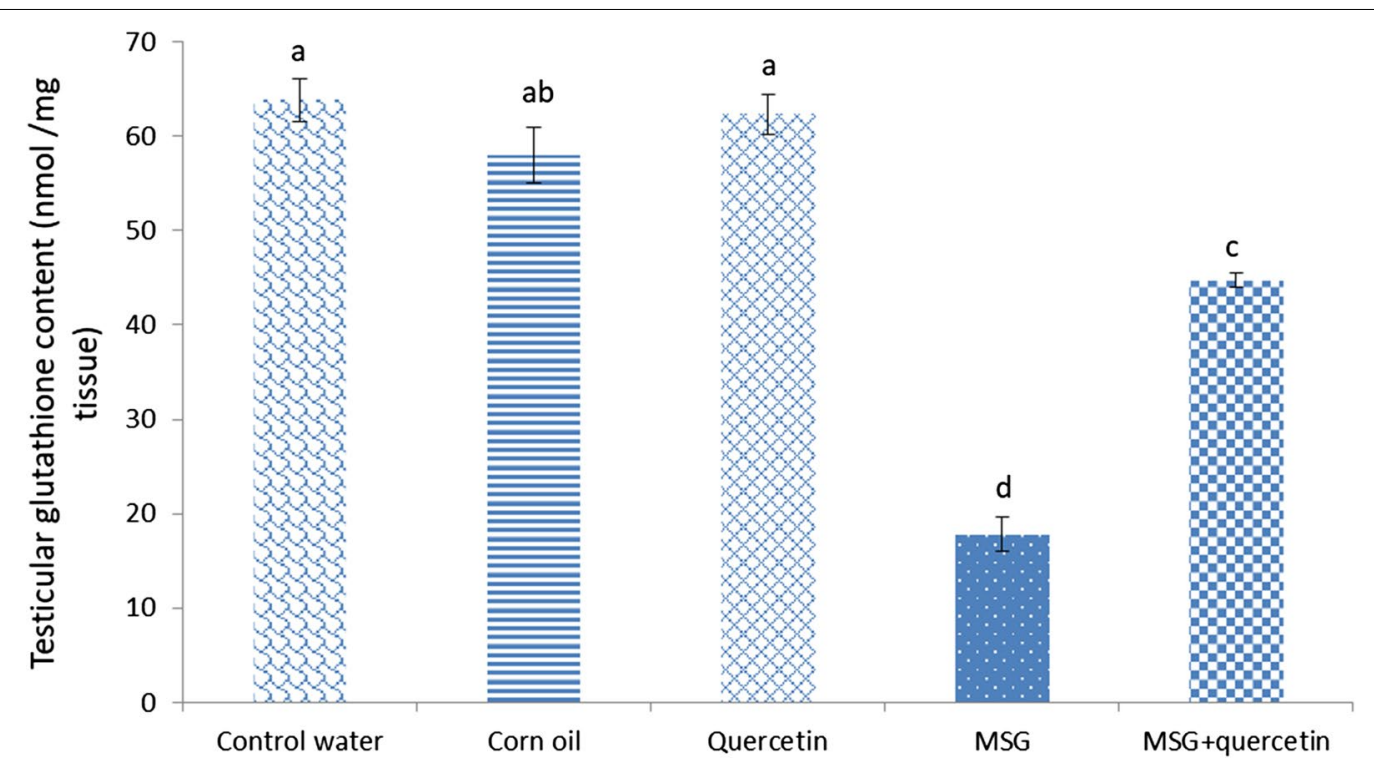

Fig. 2 Effect of quercetin on the level of glutathione content (nanomole per milligram tissue) in testis homogenate of MSG-intoxicated male rats for 30 days. The number of samples in each group is six.Values were expressed as mean \pm standard error. Means which share different superscript symbol(s) are significantly different at $P<0.001$

showed numerous histological abnormalities (Fig. 7ad). Irregular, shrunken and disorganized seminiferous tubules were observed (Fig. 7a). Congested blood vessels are also seen in (Fig. $7 \mathrm{a}$ and b). Degenerated interstitial tissue, irregular variable-sized seminiferous tubules, and apparent reduction in spermatogenic cells and sperms numbers (Fig. 7b). Moreover, detachment of germ cells from the basal lamina and cytoplasmic vacuolation were also seen (Fig. 7c). Pyknotic nuclei, vacuolation, sloughing of spermatogonia cells into the lumen of seminiferous tubules, decrease in number of sperms and widening of intercellular spaces are seen in (Fig. 7d). Testes treated with MSG and quercetin (Fig. 8a and b) revealed a significant amelioration 


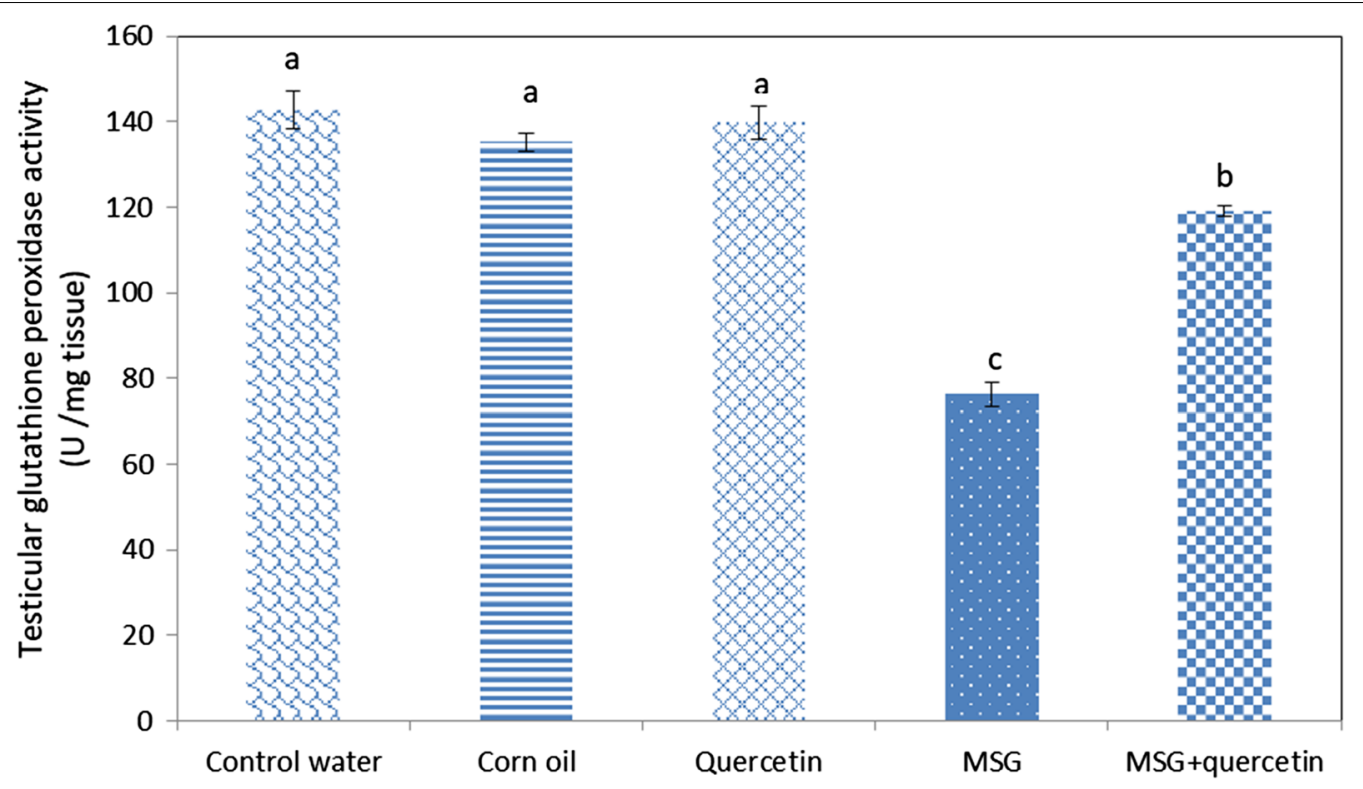

Fig. 3 Effect of quercetin on the level of glutathione peroxidase (unit per milligram tissue) in testis homogenate of MSG-intoxicated male rats for 30 days. The number of Values were expressed as mean \pm standard error. Means which share different superscript symbol(s) are significantly different at $P<0.001$

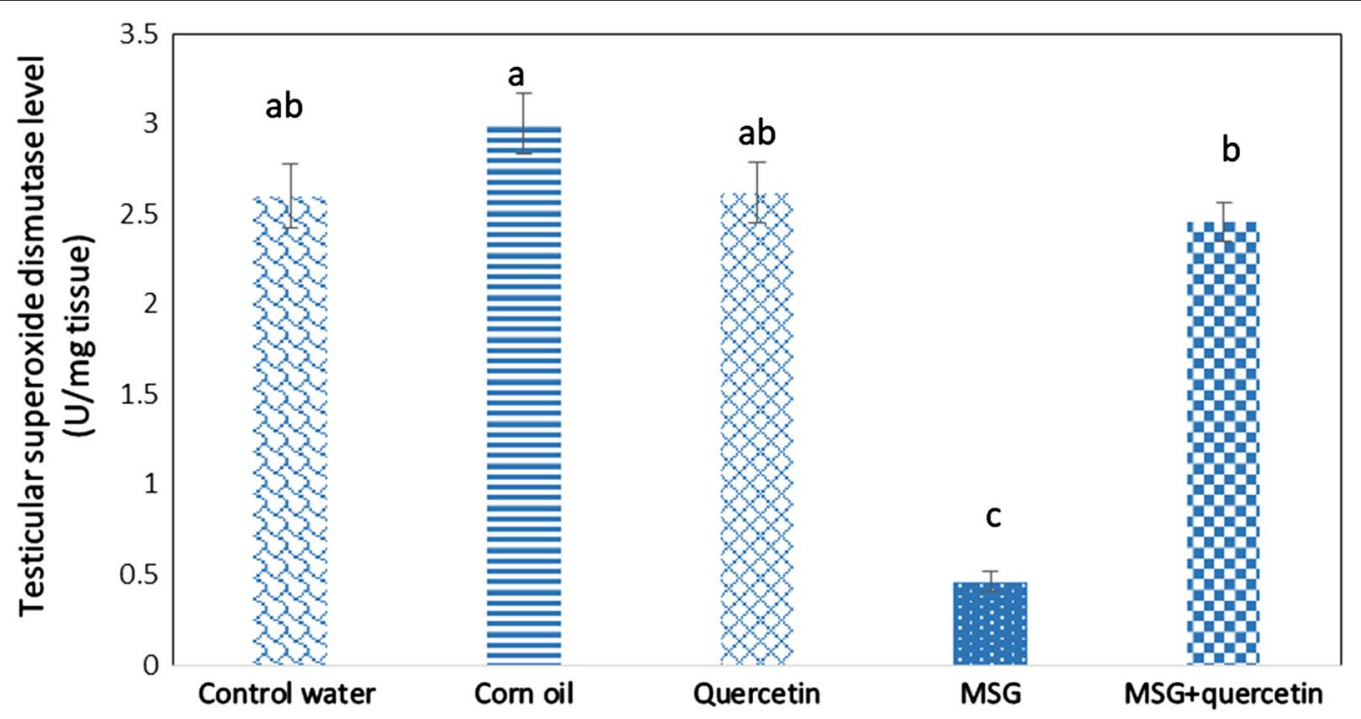

Fig. 4 Effect of quercetin on the level of superoxide dismutase (unit per milligram tissue) in testis homogenate of MSG-intoxicated male rats for 30 days. The number of samples in each group is six.Values were expressed as mean \pm standard error. Means which share different superscript symbol(s) are significantly different at $P<0.001$

in testis structure. Tubules of MSG rats treated with quercetin restored their normal shape, spermatogenic layers and sperms except some tubules still have a marked decrease in the number of sperms and vacuolation.

\subsection{Ultrastructure evaluation}

Electron microscopic examination of the testis of control rats showed each seminiferous tubule to be lined with spermatogonia that attached to the thin basal lamina, primary spermatocytes having mitochondria and 


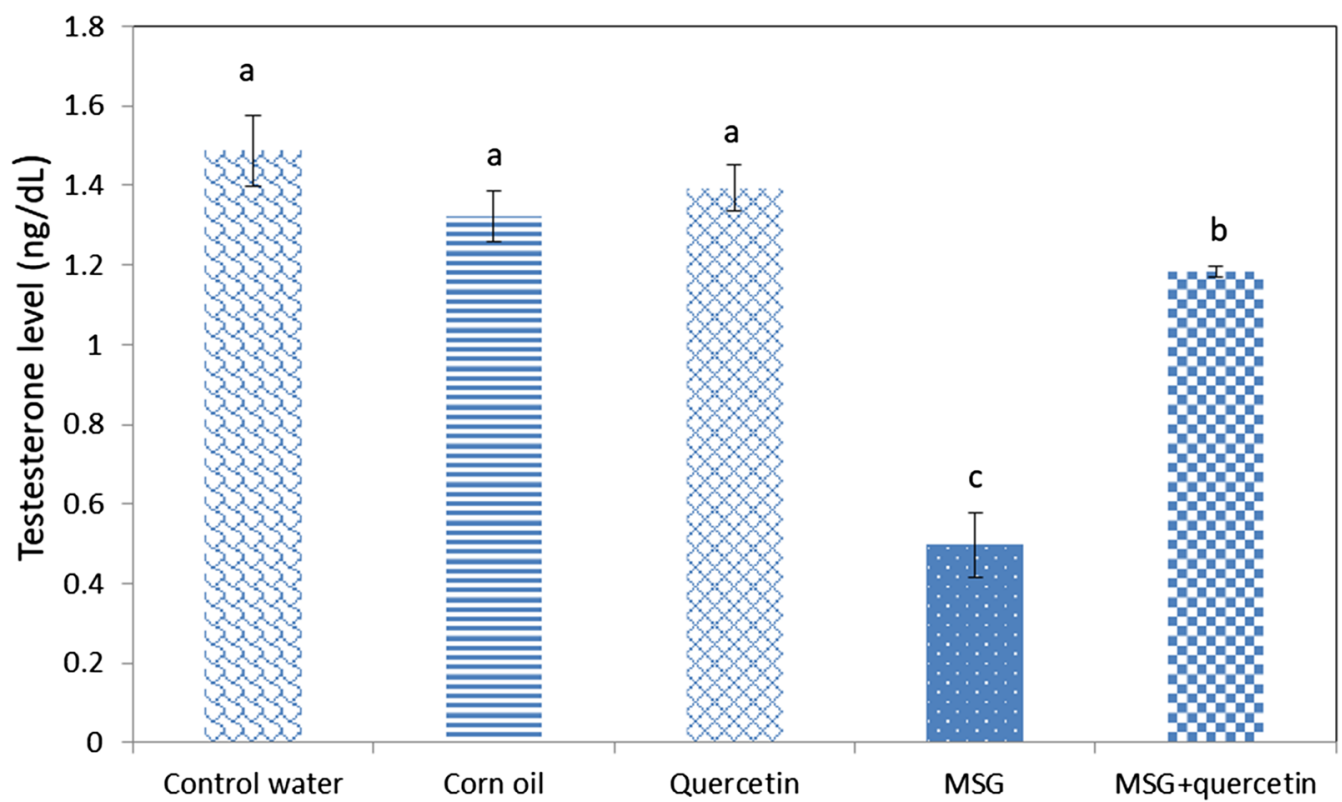

Fig. 5 Effect of quercetin on testosterone level (ng/dl) of MSG-intoxicated male rats. The number of samples in each group is six. Values were expressed as mean \pm standard error. Means which share different superscript symbol(s) are significantly different at $p<0.05$

large spherical nuclei (Fig. 9a and b). Sertoli cells have a triangular nucleus (Fig. 9b). Round spermatids with spherical nucleus, Note the differentiated part of acrosome (Fig. 9c). Cross-sections at the midpiece of sperms' tails containing 9 mitochondria and microtubules are observed (Fig. 9d and e). Leydig cells with a normal nucleus and a marked increase in lipid droplets are seen (Fig. 9f).

The MSG-treated group revealed ultrastructural alterations vacuolization in spermatogenic cells, autolysis in spermatognia, and primary spermatocytes with a damaged nucleus and fragmented chromatin (Fig. 10a). Also, Sertoli cell with vacuolation is observed (Fig. 10b). Separation of part of the round spermatids with a degenerated nucleus, cytoplasmic vacuoles, damaged mitochondria and lysosomes are seen (Fig. 10c). Spermatid with irregular membrane, increased intercellular spaces and marked decrease in the number of sperms in lumen of seminiferous tubule (Fig. 10d). Degenerated interstitial tissues, Lydeig cells with abnormal nuclei, dilated rough endoplasmic reticulum and rapture of the nuclear membrane are observed in (Fig. 10e).

The treatment of MSG rats with quercetin led to a significant improvement in testis tissues. The basement membrane was thin, spermatogonia and Sertoli cells looked normal with normal nucleus (Fig. 11a). The primary spermatocytes retained their normal organelles except for the presence of some vacuoles (Fig. 11b). The round and late spermatids retained their normal structure and the moderate number of sperms appeared in (Fig. 11c). Leydig cells with normal nucleus, mitochondria, and lipid droplets (Fig. 11d).

\section{Discussion}

Despite its widespread usage as a flavor enhancer in cooking, monosodium glutamate (MSG) is reported as a toxic agent that affects the structure and function of the male reproductive system in both humans and experimental animals [50]. The current study investigated the biochemical, histopathological, and ultrastructure alternations resulted from MSG-induced toxicity in the testis of adult rats. This study also assessed the amelioration effects of QU against MSG-induced testicular toxicity in rats.

MSG-induced testicular toxicity could be attributed to ROS-induced oxidative stress and lipid peroxidation. MSG has been reported to cause oxidative damage in testis $[17,34,51,52]$.

Our data revealed that MSG administration resulted in an elevation in the level of lipid peroxidation in form of (MDA) in testis tissue of MSG-treated rats. The increased level of lipid peroxidation resulted in oxidative damage to the development of spermatozoa, which alters membrane functions according to [53, 54]. In the current study, the elevation in MDA is also accompanied by depletion in the activity of antioxidant enzymes like, GSH, GPx and SOD which is considered as markers of cell damage according to Armand et al. [55], who mentioned that the high 


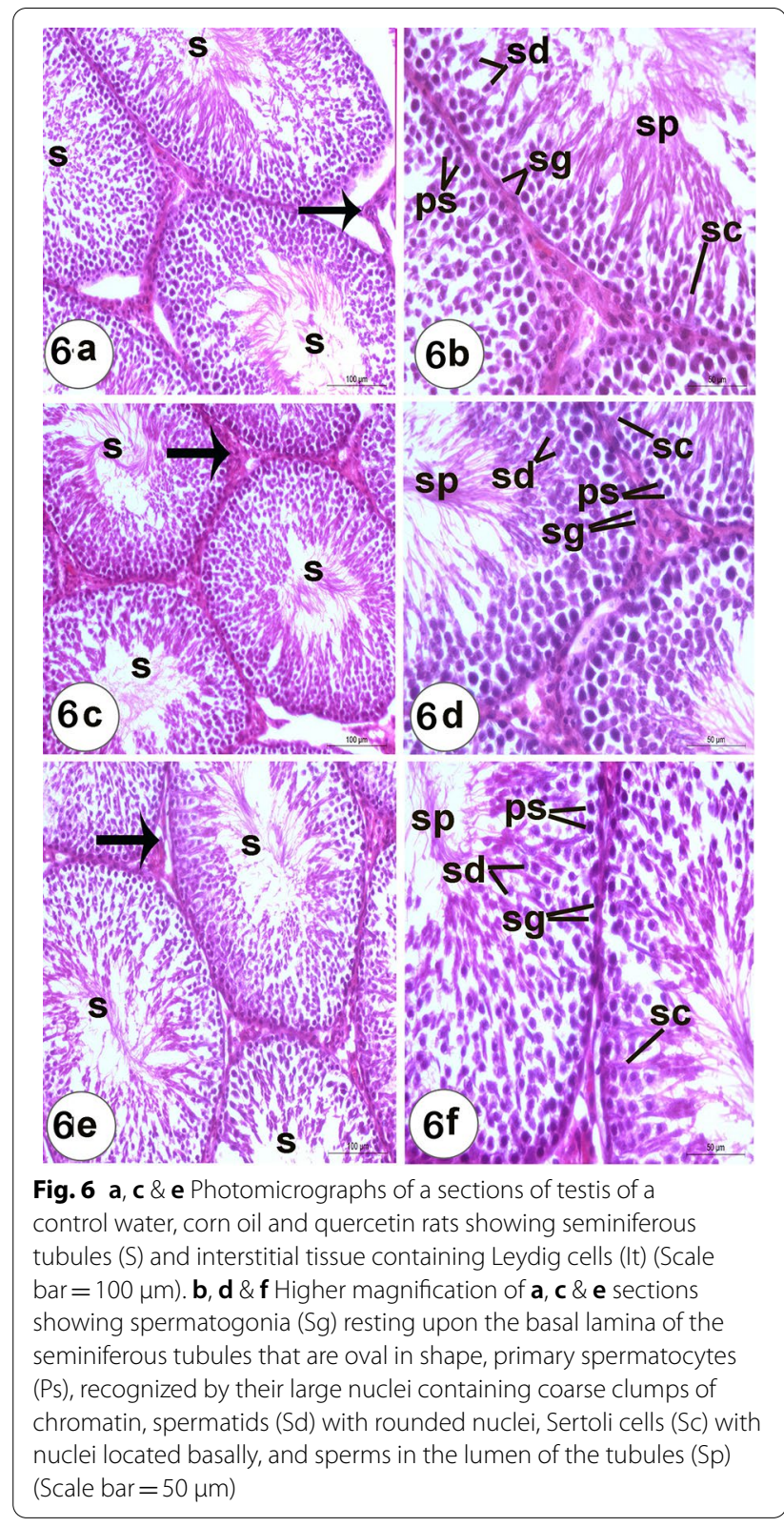

ROS in the tissues and the depletion of antioxidants have been identified as primary promoters of cellular damage whereas inhibition of membrane transport protein and enhanced lipid peroxidation are merely markers of cell harm.

Our findings support the argument which suggested that monosodium glutamate (MSG) exposure induces lipid peroxidation and oxidative damage in $[51,52,56]$ which may result in a decrease of ascorbic acid level [57]. Ascorbic acid is an endogenous antioxidant that presents in the testes to protect it from oxidative damage. When monosodium glutamate (MSG) induces

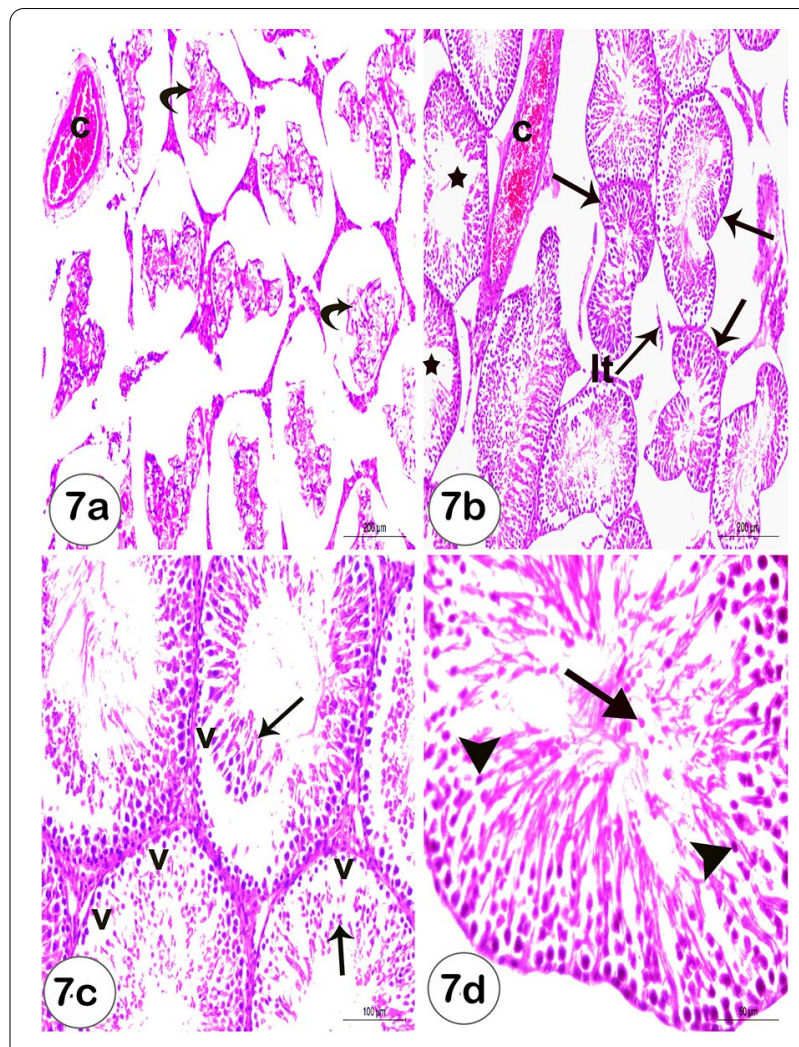

Fig. 7 a-d Photomicrographs of a sections of testis of MSG-treated male rats showing (a) Irregular, shrinked and disorganized structure and remainant of damaged seminiferous epithelium (curved arrows) and congested blood vessel (c) (Scale bar $=200 \mu \mathrm{m})$. b Degenerated interstitial tissue (it), irregular variable-sized seminiferous tubules(arrows) and many tubules (star) showed a decrease in the number of spermatogenic cells to a few layers and few or no sperms were observed (Scale bar $=200 \mu \mathrm{m}$ ). c Detachment of germ cells from basal lamina (arrows) and cytoplasmic vacuolation (v) (Scale bar $=100 \mu \mathrm{m}$ ). $\mathbf{d}$ Pyknosis of nuclei (arrow head) and sloughing of spermatogonia cells into the lumen of seminiferous tubules (arrow) (Scale bar $=50 \mu \mathrm{m}$ )

oxidative damage to testis, the cell used ascorbic acid as a ROS scavenger which explains the depletion in its level $[19,34,58]$.

Moreover, the current biochemical study revealed a decrease of serum testosterone levels of MSG-treated rats in comparison to the control group. These results are inconsistent with the findings $[59,60]$.

The reduction in blood testosterone levels observed in the current investigation might be due to a direct harmful impact of Leydig cells which are responsible for the synthesis of testosterone hormone [61]. In another study, the researcher suggested that MSG administration destroys neurons of the hypothalamus which can lead to disturbance of the hypothalamic-pituitary-testis regulatory axis, which regulates testosterone synthesis 


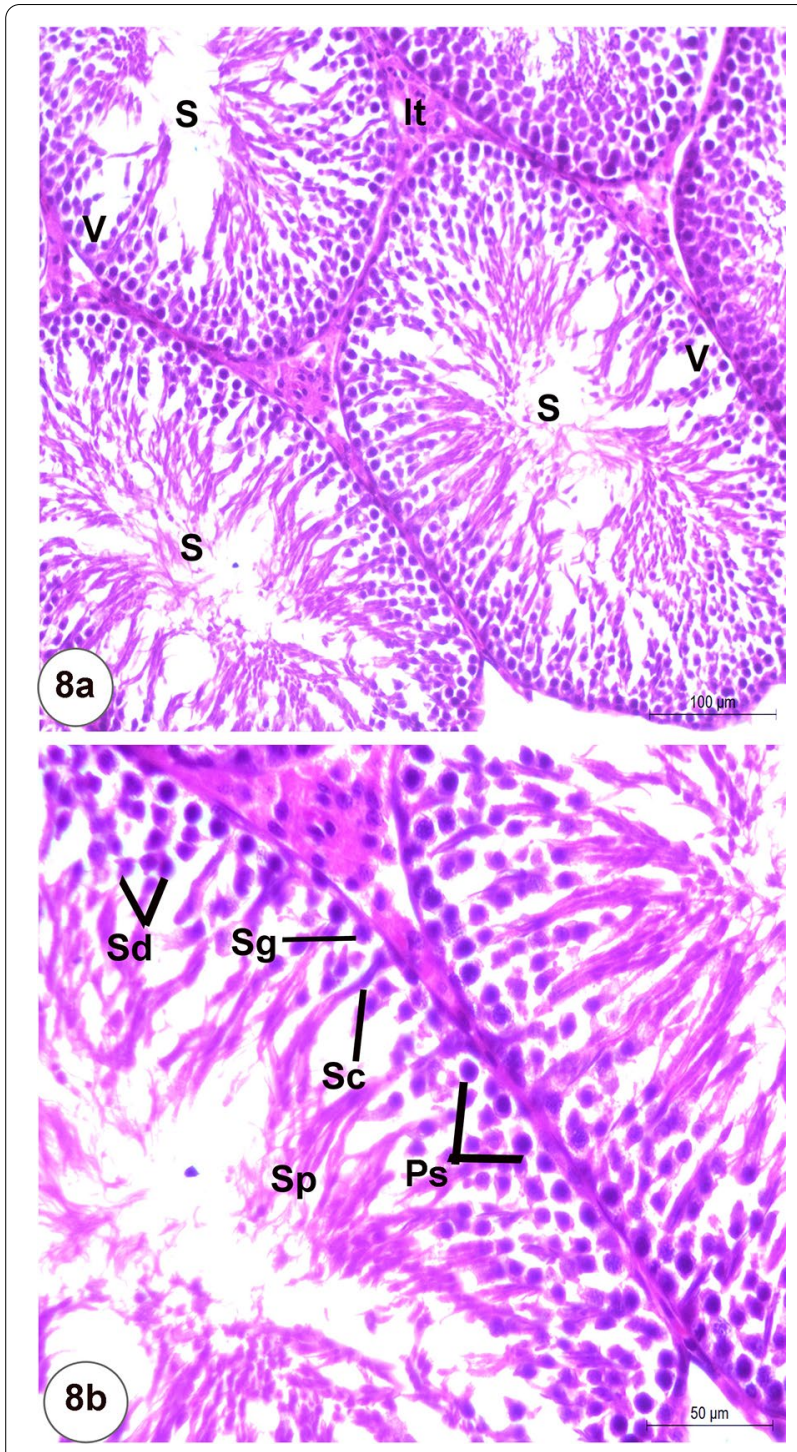

Fig. 8 Photomicrographs of a section of testis of MSG group treated with quercetin showing (a) Seminiferous tubules (S) and interstitial containing Leydig cells (It) and cytoplasmic vacuolation (v) (Scale bar $=100 \mu \mathrm{m})$. b Higher magnification of same section showing spermatogonia $(\mathrm{Sg}$ ) resting upon the basal lamina of the seminiferous tubules that are oval in shape, primary spermatocytes (Ps), recognized by their large nuclei containing coarse clumps of chromatin, spermatids (Sd) with rounded nuclei, Sertoli cells (Sc) with nuclei located basally, and sperms in the lumen of the tubules (Sp) (Scale bar $=50 \mu \mathrm{m})$

by testicular Leydig [62, 63]. This disturbance might explain the reduction in serum testosterone levels seen in the current study.

In harmony with prior research findings $[15,18$, $20,64]$, the present investigation of histopathological results of MSG-treated rats represented by alterations

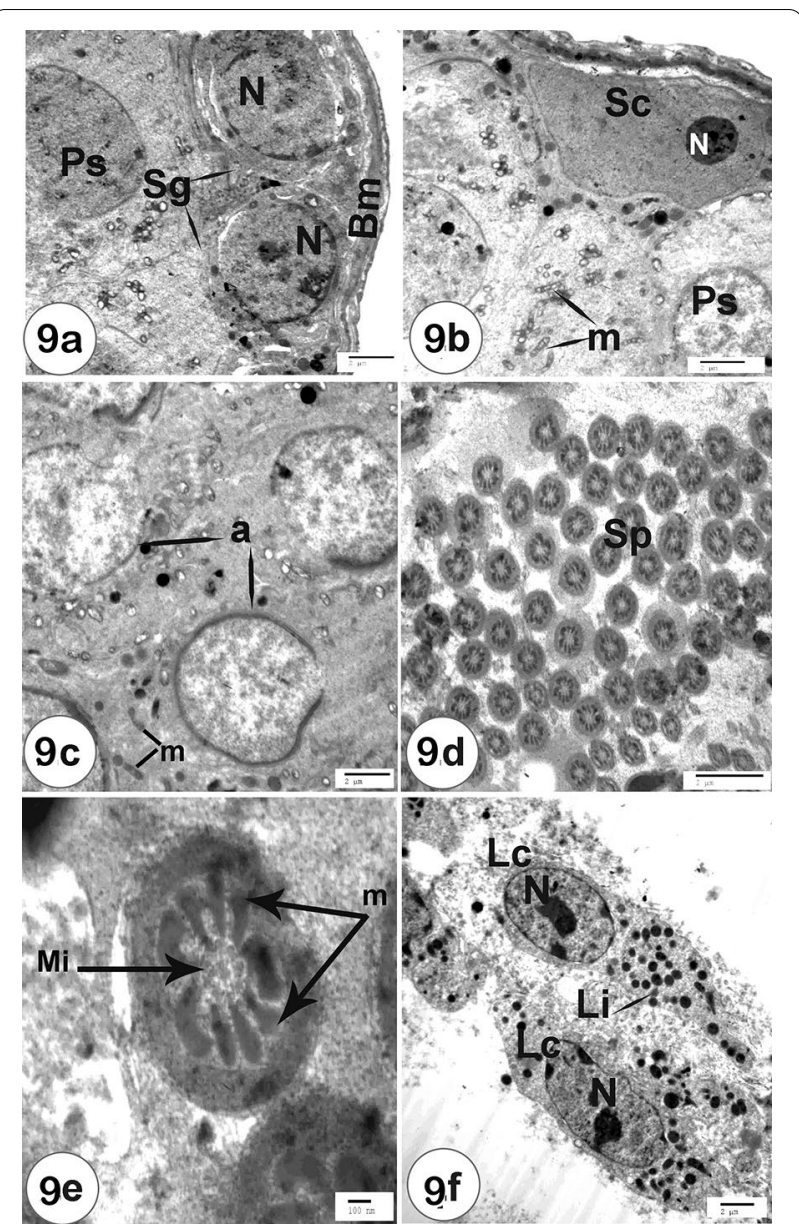

Fig. 9 Electron micrograph of a sections of testis of (control water, corn oil and quercetin) rats showing (a) basal lamina (Bm) of seminiferous tubules and spermatogonia $(\mathrm{Sg})(\mathrm{Scale} b a r=2 \mu \mathrm{m})$, b Sertoli cells ( $\mathrm{Sc}$ ) having triangular nucleus and primary spermatocytes (Ps) having mitochondria (M) and large spherical nuclei (Scale bar $=2 \mu \mathrm{m})$, c spermatids (Sd) with spherical nucleus, Note the differentiated part of acrosome (a) (Scale bar $=2 \mu \mathrm{m}), \mathbf{d}$ cross section of sperms'tails (Sp) at the level of mid piece (Scale bar $=2 \mu \mathrm{m})$, e higher magnification of $\mathbf{d}$ showing cross section of a spermatozoan (Sp) at the mid piece containing 9 mitochondria (M) and microtubules (Mi) (Scale bar $=100 \mathrm{~nm}$ ) and $\mathbf{f}$ Leydig cell (LC) with normal nucleus (N) and marked increase in lipid droplets (Li) (Scale bar $=2 \mu \mathrm{m})$

of the seminiferous tubules which included atrophied seminiferous tubules, decrease in bundles of sperms, pyknotic nuclei, dilated and congested intertubular blood vessels, and cytoplasmic vacuolation.

Cytoplasmic vacuolation is considered as defense mechanism against harmful oxidative stress effects and vacuoles may collect these damaging substances preventing them from interfering with the biological activities of these cells $[65,66]$. Therefore, current study postulated that cytoplasmic vacuolation that appeared 


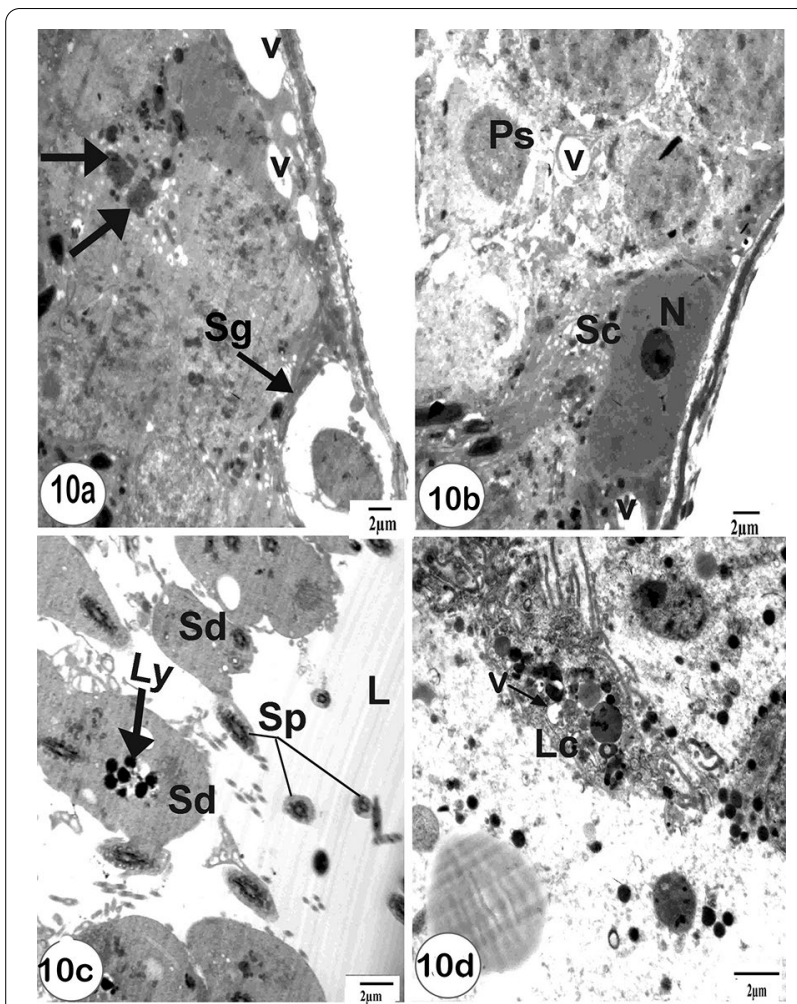

Fig. 10 An electron micrograph of sections of testis of MSG-treated rats showing a vacuolation in spermatogenic cells (v), autolysis in spermatogonia (Sg) and primary spermatocytes (Ps) with damaged nucleus and fragmented chromatin (arrows) (scale bar $=2 \mu \mathrm{m}), \mathbf{b}$ Sertoli cell (Sc) and primary spermatocytes (Ps) with vacuolation (v) (scale bar $=2 \mu \mathrm{m}), \mathbf{c}$ spermatids (Sd) with active lysosomes (Ly), degenerated nucleus and marked decrease in number of sperms (Sp) in lumen $(\mathrm{L})$ of seminiferous tubules (scale bar $=2 \mu \mathrm{m}$ ) and (e) Lydeig cells with abnormal nucleus and vacuolation (v) (scale bar $=2 \mu \mathrm{m}$ )

in testis might be a result of testicular toxicity and cell degeneration triggered by MSG according to [2, 65].

Pyknosis of cell nuclei may clear the loss of functional efficiency of the cells [67]. Balasubramanian et al. [68] revealed that congestion of blood vessels observed in testicular tissue of MSG-treated rats is related to the suppression of prostaglandin production, which is known to be involved in the control of testicular circulation.

The current ultrastructure investigation of the testis of MSG-treated rats shows degeneration of Sertoli cells and spermatogenic cells, primary spermatocyte and Leydig cells with numerous cytoplasmic vacuoles and damaged mitochondria [69, 70] explained these vacuoles by degeneration of abnormal germ cells resulting in wide gaps between nearby Sertoli cells. The current work also recorded enlarged intercellular spaces between spermatid, shrunken nuclei, irregular distribution of mitochondria and lysosomes in accordance with [71].

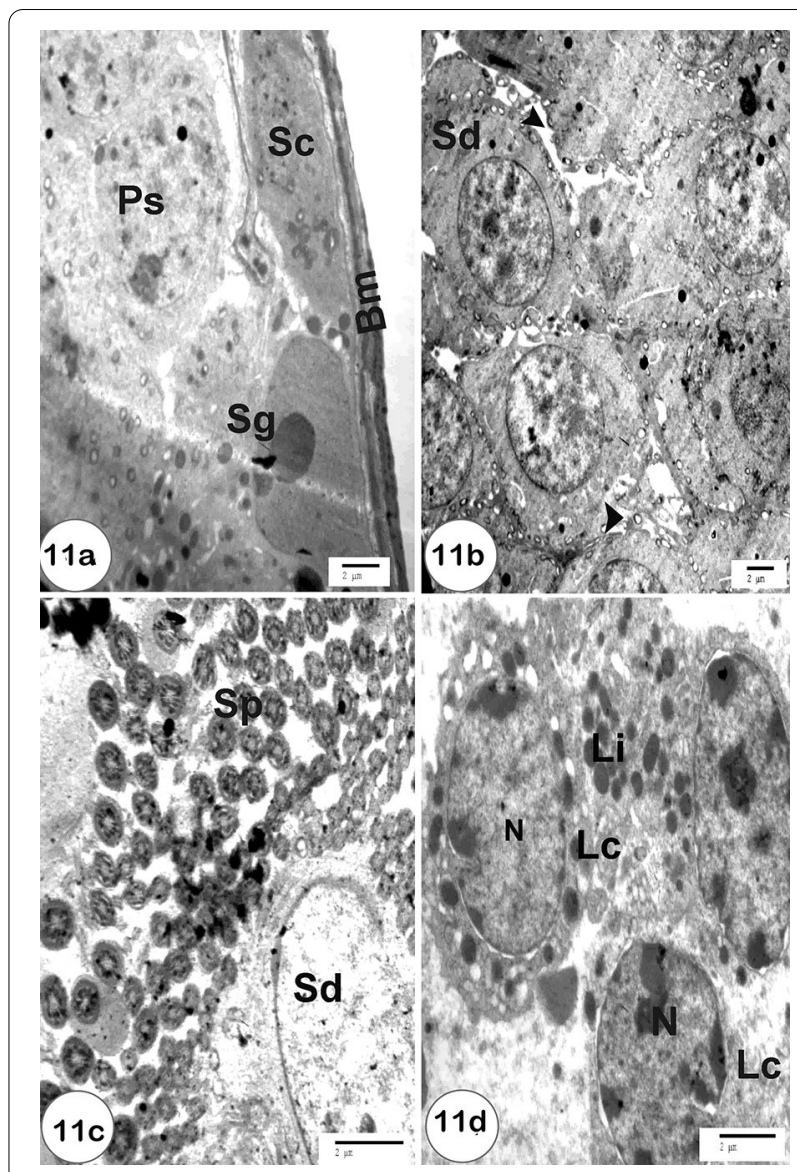

Fig. 11 An electron micrograph of a sections of testis of

MSG-intoxicated rats treated with quercetin showing a basal lamina $(\mathrm{Bm})$ of seminiferous tubules, primary spermatocytes (Ps) with normal large spherical nuclei and Sertoli cells (Sc) having triangular nucleus (Scale bar $=2 \mu \mathrm{m}$ ), b normal round spermatids (Sd) with spherical nucleus (Scale bar $=2 \mu \mathrm{m}$ ), $\mathbf{c}$ cross section of sperms'tails (Sp) at the level of mid piece and normal spermatids (Sd) (Scale bar $=2 \mu \mathrm{m})$ and d Leydig cell (LC) with normal nucleus (N) and lipid droplets (Li) (Scale bar $=2 \mu \mathrm{m})$

The histopathological and ultrastructure damage of testis may be explained by different mechanisms. First, MSG can directly influence testicular epithelial cells via functioning glutamate transporters and receptors in rat testes, inhibiting spermatogenesis [64, 72, 73]. The second mechanism suggested that MSG-induced oxidative damage may destroy most of the testicular germ cells and result in a decrease in testicular weight [57].

In the present investigation quercetin remarkably diminished the testicular histological and morphometric alterations produced by numerous toxic substances Uygur et al. [74].

As one of the strong antioxidants, quercetin can impact the redox state of cells by boosting the expression of c-glutamylcysteine synthetase, the rate-limiting 
enzyme in the production of GSH. [75, 76]. Amália et al. [77] have also reported that quercetin acts as a promoter enhanced SOD and GPx levels.

Quercetin substantially reduced lipid peroxidation and boosted the antioxidant activity of SOD, GPx, and GSH concentrations in the current research. These results are in accordance with [78-80].

Our data also revealed that QU treatment enhanced testosterone levels in MSG-treated animals. These findings are in agreement with Khaki et al. [81] who reported that testosterone levels in diabetic animals enhanced after the treatment with QU.

So, the present data showed that many histological alterations and ultrastructure changes as well as the change in serum testosterone level induced by MSG in testis of rats were significantly improved after treatment with quercetin. The presence of aromatic hydroxyl groups in quercetin's structure, which serve as ROS scavengers, is responsible for its high antioxidant effects. [29, 82].

\section{Conclusions}

Our study concluded that quercetin can efficiently modulate the MSG-induced toxicity in the rat testis and this action appears to rely mainly on QU's antioxidant properties. Our study showed that quercetin supplementation ameliorated the MSG-induced oxidative damage which was marked by lipid peroxidation, a decrease in enzymatic antioxidant (GPx and SOD), and non-enzymatic antioxidant (GSH), and low testosterone levels as well as severe histopathological and ultrastructure changes in the testis.

\section{Abbreviations}

GPX: Glutathione peroxidase; GSH: Glutathione; MDA: Malondialdehyde; MSG: Monosodium glutamate; QU: Quercetin; ROS: Reactive oxygen species; SOD: Superoxide dismutase.

\section{Acknowledgements}

Not applicable.

\section{Authors' contributions}

All authors have contributed significantly, Prof. Dr. MA, Dr. Prof. SRG, and Prof. Dr. RRA have contributed in suggesting design of the work, preparation and analysis of the results, interpretation of data and discussion. In addition, $\mathrm{Mr}$. $\mathrm{HMH}$ has performed the practical part. All authors are in agreement with the contents of the manuscript. All authors read and approved the final manuscript.

\section{Funding}

Not applicable.

\section{Availability of data and materials}

All data generated or analysed during this study are included in this published article.

\section{Declarations}

Ethics approval and consent to participate

All animal procedures were conducted in accordance with the standards set forth in the guidelines for the care and use of experimental animals by the Animal Ethics Committee of the Zoology Department in the Faculty of Science at Beni-Suef University (Approval number is BSU/FS/ 2015/9).

\section{Consent for publication}

Not applicable.

\section{Competing interests}

The authors declare that they have no competing interests.

Received: 22 July 2021 Accepted: 19 October 2021

Published online: 29 October 2021

\section{References}

1. Freeman M (2006) Reconsidering the effects of monosodium glutamate. A literature review. J Am Acad Nurse Pract 18(10):482-486

2. Alalwani AD (2014) Monosodium Glutamate induced testicular lesions in rats (histological study). Mid E Fert Soci J 19(4):274-280

3. Inuwa HM, Aina VO, Gabi B, Aim O, Ja'afaru L, (2011) Determination of nephrotoxicity and hepatoxicity of monosodium glutamate (MSG) consumption. B J Pharmacol Toxicol 2(3):148-153

4. Ali AA, El-Seify GH, El Haroun HM, Abd El Mawla M, Soliman M (2014) Effect of monosodium glutamate on the ovaries of adult female albino rats and the possible protective role of green tea. Menoufia Med J 27:793-800

5. Populin T, Moret S, Truant S, Conte LS (2007) A survey on the presence of free glutamic acid in foodstuffs, with and without added monosodium glutamate. Food Chem 104:1712-1717

6. Silva GMSW, Wansapala MAJ (2016) Determination of antioxidant activity and phytochemical compounds in natural flavor enhancer. Res $\mathrm{J}$ chem sci 6(10):13-18

7. Yoshida Y (1998) Umami taste and traditional seasoning. Food Rev Int 14(2):213-246

8. Niaz K, Zaplatic E, Spoor J (2018) Extensive use of monosodium glutamate: a threat to public health? EXCL J 17:273-278

9. Husarova V (2013) Ostatnikova D (2013) Monosodium glutamate toxic effects and their implications for human intake: a review. JMED Research 2013:12

10. Beas-Zarate C, Perez-Vega MI, Gonzalez-Burgos I (2002) Neonatal exposure to monosodium L-glutamate induces loss of neurons and cytoarchitectural alternations in hippocampal CA1 pyramidal neurons of adult rats. Brain Res 952:275-281

11. Kotb SM, El-Ghazouly D, Ameen O (2020) The potential cytoprotective effect of Vitamin C and Vitamin E on monosodium glutamate-induced testicular toxicity in rats. Alex J Med 56:134-147

12. Collison KS, Makhoul NJ, Zaidi MZ, Al-Rabiah R, Inglis A, Andres BL, Ubungen R, Shoukri M, Al-Mohanna FA (2012) Interactive effects of neonatal exposure to monosodium glutamate and aspartame on glucose homeostasis. Nutr Metab 9(1):58

13. Elatrash AM, Abd El-Haleim SZ (2015) Protective role of ginkgo biloba on monosodium glutamate: induced liver and kidney toxicity in rats. Res J Pharma Bio Chem Sci 6(1):1433

14. Bojanic V, Bojanic Z, Najman S, Savic T, Jakovl-jevic V, Najman S, Jancic S (2009) Diltiazem prevention of toxic effects of monosodium glutamate on ovaries in rats. Gen Physiol Biophys 28:149-154

15. Das RS, Ghosh SK (2011) Long term effects in ovaries of the adult mice following exposure to Monosodium glutamate during neonatal life-a histologicalstudy. Nepal Med Coll J 13(2):77-83

16. Pavlovic V, Pavlovic D, Kocic G, Sokolovic D, Jevtovic-Stoimenov T, Cekic S, Velickovic D (2007) Effect of monosodium glutamate on oxidative stress and apoptosis in rat thymus. Mol Cell Biochem 303(1-2):161-166

17. Kayode OT, Rotimi DE, Kayode AA et al (2020) Monosodium Glutamate (MSG)-induced male reproductive dysfunction: a mini review. Toxics $8(1): 7$ 
18. Sakr SA, Badaw GM (2013) Protective effect of curcumin on monosodium glutamate-Induced reproductive toxicity in male albino rats. Global Pharmacol J 7(4):416-422

19. Nayanatara A, Vinodini N, Damadar G, Ahemed B, RamaswamyC SM, Bhat M (2008) Role of ascorbic acid in monosodium glutamate mediated effect on testicular weight sperm morphology and sperm count in rat testis. J Chin Clin Med 3:1-5

20. Nosseir NS, Ali MM, Ebaid HM (2012) A histological and morphometric study of monosodium glutamate toxic effect on testicular structure and potentiality of recovery in adult albino rat. Res J Biol 2(2):66-78

21. Estrada JE, Bescós P, Villar De Fresno AM (2001) Antioxidant activity of different fractions of Spirulina platensis protean extract. II Farmaco 56:497-500

22. Colla LM, Muccillo-Baisch AL, Costa JV (2008) Spirulina platensis effects on the levels of total cholesterol, HDL and triacylglycerols in rabbits fed with a hypercholesterolemic diet. Braz Arch Biol Technol 51 (2):405-411

23. Bertolin TE, Pilatti D, Giacomini AC, Bavaresco C, Colla LM, Costa JAV (2009) Effect of microalga spirulina platensis (arthrospira platensis) on hippocampus lipoperoxidation and lipid profile in rats with induced hypercholesterolemia. Braz Arch Biol Technol 52(5):1253-1259

24. Lakhanpal P, Kumar DR (2007) Quercetin: a versatile flavonoid. Internet J Med updates 2(2):22-37

25. Gupta SC, Kismali G, Aggarwal BB (2013) Curcumin, a component of turmeric: from farm to pharmacy. BioFactors 39(1):2-13

26. Lin CF, Leu YL, Al-Suwayeh SA, Ku MC, Hwang TL, Fang JY (2012) Antiinflammatory activity and percutaneous absorption of quercetin and its polymethoxylated compound and glycosides: the relationships to chemical structures. Eur J Pharm Sci 47:857-864

27. Capasso R, Aviello G, Romano B, Atorino G, Pagano E, Borrelli F (2009) Inhibitory effect of quercetin on rat trachea contractility in vitro. J Pharm Pharmacol 61:115-119

28. Maalik A, Khan FA, Mumtaz A, Mehmood A, Azhar S, Atif M, Karim S, Altaf Y, Tariq I (2014) Pharmacological applications of quercetin and its derivatives: a short review. Tropic J Pharma Res 13(9):1561-1566

29. Du Thie G, Crozier A (2000) Plant derived phenolic antioxidants. Curr Opin Clin Nutr Metab 3:447-451

30. Baltaci, R. Uygur, Caglar V, Aktas C, Aydin M, Ozen OA (2016) Protective effects of quercetin against arsenic-induced testicular damage in rats. Andrologia 48:1202-1213

31. Casagrande R, Georgetti SR, Verri WA Jr, Dorta DJ, dos Santos AC, Fonseca MJ (2006) Protective effect of topical formulations containingquercetin against UVB-induced oxidative stress in hairless mice. J Photochem Photobiol B 84:21-27

32. Fuhrman B, Aviram M (2001) Flavonoids protect LDL from oxidation and attenuate atherosclerosis. Curr Opin Lipidol 12:41-48

33. Yousef MI, Omar S, El-Guendi MI, Abdelmegid LA (2010) Potential protective effects of quercetin and curcumin on paracetamol-induced histological changes, oxidative stress, impaired liver and kidney functions and haematotoxicity in rat. Food Chem Toxicol 48:3246-3261

34. Onyema OO, Farombi EO, Emerole GO, Ukoha Al, Onyeze GO (2006) Effect of vitamin $\mathrm{E}$ on monosodium glutamate induced hepatotoxicity and oxidative stress in rats. Indian J Biochem Biophys 43:20-24

35. Farombi EO, Onyema $\mathrm{OO}$ (2006) Monosodium glutamate-induced oxidative damage and genotoxicity in the rat: modulatory role of vitamin $C$ vitamin $E$ and quercetin. Hum Exp Toxicol 25(5):251-259

36. Firgany AEL, Sarhan NR (2020) Quercetin mitigates monosodium glutamate-induced excitotoxicity of the spinal cord motoneurons in aged rats via p38 MAPK inhibition. Acta Histochem 122(5):151554

37. Andres S, Pevny S, Ziegenhagen R, Bakhiya N, Schäfer B, Hirsch-Ernst KI, Lampen A (2018) Safety aspects of the use of quercetin as a dietary supplement. Mol Nutr Food Res 62:1

38. Velázquez KT, Enos RT, Narsale AA, Puppa MJ, Davis JM, Murphy EA, Carson JA (2014) Quercetin supplementation attenuates the progression of cancer cachexia in ApcMin/+ mice. J Nutr 144(6):868-875

39. Egbuonu C, Cemaluk K, Osakwe ON (2011) Effects of high monosodium glutamate on some serum markers of lipid status in male Wistar rats. J Med Med Sci 2(1):653-656

40. Preuss HG, Jarrell ST, Scheckenbach R, Lieberman S, Anderson RA (1998) Comparative effects of chromium, vanadium and gymnema sylvestre on sugar-induced blood pressure elevations in SHR. J Am Coll Nutr 17(2):116-123
41. Beutler E, Duron O, Kefly BM (1963) Improved method for the determination of blood glutathione. Lab and Clin Med 61:882-888

42. Paglia DE, Valentine WN (1967) Studies on the quantitative and qualitative characterisation of erythrocyte glutathione peroxidase. J Lab Clin Med 70:158-169

43. Nishikimi M, Appaji N, Yagi K (1972) The occurrence of superoxide anion in the reaction of reduced phenazine methosulfate and molecular oxygen. Biochem Biophys Res Commun 46:849-854

44. Huang HF, Marshall GR, Rosenberg R, Nieschlag E (1987) Restoration of spermatogenesis by high levels of testosterone in hypophysectomised rats after long-term regression. Acta Endocrinol 116: 433444

45. Darney KJ Jr, Zirkin BR, Ewing LL (1996) Testosterone autoregulation of its biosynthesis in the rat testis: inhibition of 17 alpha-hydroxylase activity. J Androl 17(2):137-142

46. Sakuma Y (2009) Gonadal steroid action and brain sex differentiation in the rat. J Neuroendocrino 21(4):410-414

47. Bancroft JD, Gamble M (2002) Theory and practice of histological techniques, 5th edn. Edinburgh, London Churchill Livingstone, p 1796

48. Bozzola JJ, Russell LD. (1999) Electron microscopy: Principles and techniques for biologists, 2nd edn. Sudbury, MA, USA

49. Roa M, Blane K, Zonneberg M (1985) One-way analysis, version 1A(C) PCSTAT. Athens, Georgia: University of Georgia

50. Moore KL (2003) Congenital malformations due to environmental factors. In: Developing humans 2nd edn. W.B. Saunders Co. Ltd, Philadelphia, pp 173-183

51. Diniz YS, Fernando AA, Campos KE, Mani F, Ribas BD, Novelli EL (2004) Toxicity of hyper caloric diet and monosodium glutamate: oxidative stress and metabolic shifting in hepatic tissue. Food Chem Toxicol 42:319-325

52. Vinodini NA, Nayanatara AK, Ramaswamy C et al (2010) Study on evaluation of Monosodium glutamate-induced oxidative damage on renal tissue on adult Wistar rats. J Chin Clin Med 5(3):144-147

53. Hamza RZ, AL-Harbi MS, (2014) Monosodium glutamate induced testicular toxicity and the possible ameliorative role of vitamin E or selenium in male rats. Toxicol Rep 1:1037-1045

54. Aitken J, Clarkson JS, Fishel S (1989) Generation of reactive oxygen species, lipid peroxidation and human sperm function. Biol Reprod 41:183-187

55. Armand Z, NajafiGh FF, ShalizarJalali A (2013) Attenuation of cyclosporine-induced sperm impairment and embryotoxicity by crataegusmonogyna fruit aqueous extract. Cell J 15(3):198-205

56. Singh P, Mann AK, Mangat HK et al (2003) Prolonged glutamate excitotoxicity: effects on mitochondrial antioxidants and antioxidant enzymes. Mol Cell Biochem 243:139-145

57. Vinodini NA, Nayanatara AK, Damodaragawda KM, Ahamad B, Shabarinath S (2008) Effect of monosodium glutamate-induced oxidative damage on rat testis. J Chin Clin Med 3(7):370-373

58. Mohamed IK (2012) The effects of oral dosage of monosodium glutamate applied for short and long terms on the histology and ultrastructure of testes of adult rats. J Anim Vet Adv 11:124-133

59. Okoye CN, Ochiogu IS, Onah CE (2016) The effects of monosodium I-glutamate administration on the reproduction and serum biochemistry of adult male rabbits. Vet Med 61(3):141-147

60. Ochiogu IS, Ogwu D, Uchendu CN, Okoye CN, Ihedioha JI, Mbegbu EC (2015) Effects of of monosodium-Lglutamate administration on serum levels of reproductive hormones and cholesterol, epididymal sperm reserve and testicular histomorphology of male albino rats. Acta Vet Hung 63:125-139

61. Movahed E, Sadrkhanlou R, Ahmadi A, Nejati V, Zamani Z (2013) Effect of purine nucleoside analogue-acyclovir on the sperm parameters and testosterone production in rats. Int J Fertil Steril 7(1):49-56

62. Mclachilan, RI, Wreford NG, O'Donnell L, DE Kretser DM, Robertson DM (1996) The endocrine regulation of spermatogenesis: independent roles for testosterone and FSH. J Endocrinol 148:1-9

63. Abd RN (2017) Effect of MSG as a food additive on organo-somatic indicator and sperms abnormalities in adult male mice. Sci J Med Res 1(2):46-50

64. Gill SS, Mueller RW, McGuire PF, Pulido OM (2000) Potential target sites in peripheral tissues for excitatory neurotransmis-sion and excitotoxicity. Toxicol Pathol 28:277-284 
65. El-Deeb R, Zakaria I, Abd El-Khalik I, Abd Ei-Aziz S (2000) The influence of short and long term treatment with Slidnafil Citrate on the testes andliver of albino rats. Egypt J Zoo 35:163-187

66. Cheville NF (2009) Ultrastructural pathology: the comparative cellular basis of disease, 2nd edn. Wiley-Blackwell. A john Wiley of Sons, Inc USA

67. Ortiz G, Bitzer-Quintero OBeas, Zárate C, Rodríguez-Reynoso C, LariosArceo F, Velázquez-Brizuela I, Pacheco-Moisés F, Rosales-Corral S (2006) Monosodium glutamate-induced damage in liver and kidney: a morphological and biochemical approach. Biomed Pharmacother 60:86-91

68. Balasubramanian A, Manimekalai S, Singh A, Ramakrishnan S (1980) Short and long-term effect of aspirin on testes of albino rats: a histological and biochemical study. Indian J Exp Biol 18:1408-1410

69. Vicentini FT, Fonseca YM, Pitol DL, Iyomasa MM, Bentley MV, Fonseca MJ (2010) Evaluationof protective effect of a water-in-oil microemulsion incorporating quercetin against UVB-induced damage in hairless mice skin. J Pharm Pharm Sci 13:274-285

70. Sinha Hikim AP, Amador AG, Bartke A, Russell LD (1989) Struc-ture/function relationship in active and inactive hamster Leydig cells: a correlative morphometric and endocrine study. Endocrinology 125:1844-1856

71. Selvakumar E, Prahalathan C, Sudharsan P, Varalakshmi P (2006) Chemoprotective effect of lipoic acid against cyclophosphamide-induced changes in rat sperm. Toxicol 217:71-78

72. Hu JH, Yang N, Ma YH, Jiang J, Zhang JF, Fei J, Guo LH (2004) Identification of glutamate transporters and receptors in mouse testis. Acta Pharmacol $\sin 25: 366-371$

73. Takarada T, Hinoi E, Balcar VJ, Taniura H, Yoneda Y (2004) Possible expression of functional glutamate transporters in the rat testis. J Endocrinol 181:233-244

74. Uygur R, Yagmurca M, Alkoc OA, Genc A, Songur A, Ucok K, Ozen OA (2014) Effects of quercetin and fish n-3 fatty acids on testicular injury induced by ethanol in rats. Andrologia 2014; 46:356-369
75. Mokhtar SAM, Omar MI, El-Guendi LA (2010) Abdelmegid a potential protective effects of quercetin and curcumin on paracetamol-induced histological changes, oxidative stress, impaired liver and kidney functions and haematotoxicity in rat Food. Chem Toxicol 48:3246-3261

76. Myhrstad MC, Myhrstad H, Carlsen O, Nordstrom R, Blomhoff JJ et al (2002) Moskaug Flavonoids increase the intracellular glutathione level by transactivation of the gamma-glutamylcysteine synthetase catalytical subunit promoter Free Radical. Biol Med 32:386-393

77. Amalia PM, Possa MN, Augusto MC, Francisca LS (2007) Quercetin prevents oxidative stress in cirrhosic rats. Dig Dis Sci 52:2616-2621

78. Rim KT (2017) Toxicological evaluation of MSG for the manufacturing workers'health: a literature review. Toxicol Environ Health Sci 9(1):1-11

79. Seiva FRF, Chuffa LGA, Braga CP, Amorim JPA, Fernandes AAH (2012) Quercetin ameliorates glucose and lipid metabolism and improves antioxidant status in postnatally monosodium glutamate-induced metabolic alterations. Food Chem Toxicol 50:3556-3561

80. Elkhateeb S, Mahmoud A, Ibrahem N (2020) Protective role of quercetin in hippocampus inflammatory and oxidative damage induced by monosodium glutamate in rats. MJFMCT 28(2):15-31

81. Khaki A, Fathiazad F, Nouri M, Khaki A, Maleki NA, Khamnei HJ, Ahmadi P (2010) Beneficial effects of quercetin on sperm parameters in streptozotocin-induced diabetic male rats. Phytother Res 24(9):1285-1291

82. Gules O, Yildiz M, Naseer Z, Tatar M (2019) Effects of folic acid on testicular toxicity induced by bisphenol-A in male Wistar rats. Biotech Histochem 94:26-33

\section{Publisher's Note}

Springer Nature remains neutral with regard to jurisdictional claims in published maps and institutional affiliations.

\section{Submit your manuscript to a SpringerOpen ${ }^{\circ}$ journal and benefit from:}

- Convenient online submission

- Rigorous peer review

- Open access: articles freely available online

- High visibility within the field

Retaining the copyright to your article

Submit your next manuscript at $\boldsymbol{\nabla}$ springeropen.com 